\title{
Evaluation of jobs in textile companies from Hidalgo-Mexico, through an instrument for job satisfaction
}

DOI: $10.35530 / I T .072 .04 .202025$

\section{ABSTRACT - REZUMAT}

Evaluation of jobs in textile companies from Hidalgo-Mexico, through an instrument for job satisfaction

In the Mexican textile industries, State of Hidalgo's especially, conditions as high temperatures, the handling of chemical substances, high noise and vibration levels, humidity, dust and others, continuously exposes workers to associated risks. Diagnosing and proposing improvements by working conditions assessments are not easy to perform, especially if this is not an essential item in the culture of those responsible for carrying them out neither have honest opinions of employees about problems or risks during work hours, without posing a threat to their current labour status. This study aims to assess 420 worker's job post, using an occupational satisfaction instrument finding the lowest rankings in ironing area.

Keywords: job evaluation, job satisfaction, company, industrial sector, work area

Evaluarea locurilor de muncă în companiile textile din Hidalgo-Mexic, printr-un instrument de satisfacție profesională

În industria textilă din Mexic, în special în statul Hidalgo, condițiile precum temperaturile ridicate, manipularea substanțelor chimice, nivelurile ridicate de zgomot și vibrații, umiditatea, praful și altele expun continuu lucrătorii la riscurile asociate. Diagnosticarea și propunerea de îmbunătătiri prin evaluările condițiilor de muncă nu sunt ușor de realizat, mai ales dacă acest lucru nu este un element esențial în cultura celor responsabili de realizarea lor și nici nu au păreri oneste ale angajaților despre problemele sau riscurile apărute în timpul orelor de lucru, fără a reprezenta o amenințare asupra statutului lor actual la locul de muncă. Acest studiu își propune să evalueze 420 locuri de muncă, utilizând un instrument de satisfacție profesională, care identifică cel mai scăzut nivel în zona de finisare prin călcare.

Cuvinte-cheie: evaluarea locului de muncă, satisfacția profesională, companie, sector industrial, zonă de lucru

\section{INTRODUCTION}

This research is part of the Management and Business Development Academic Group's activities in Institute of Economic and Administrative Sciences of The Autonomous University of the State of Hidalgo (UAEH). It was conducted to assess job posts among 420 textile workers in Hidalgo State, Mexico, using an instrument for job satisfaction measurement.

Theoretical evidence has emphasized the importance of knowing factors that affects employees' performance in their jobs [1-3]. This study will contribute to sensitize managers and business owners to allow a larger investigation in a short term, to evaluate and qualify each job in a more technical way, looking to improve productive performance and reduce occupational risks of factors that negatively affect workers health and well-being.

\section{JOBS EVALUATION}

Modern businesspersons are more sensitive to technological advances and the environment where their employees carry out their duties in; however, just a few of them really concerns about examining how the job characteristics effects on workers' health. For this reason, it is important for directors, especially those responsible for personnel management, being aware of factors that affect the employees' health and safety, such as the attitudes of workers and accidents at work [4].

In companies, security provided by a healthy work environment implies a reduction in risks at work and suffering professional injuries or illnesses, so, can generate the perception of job satisfaction, physical and mental well-being in employees [5]. Although currently, the Secretary of Labour and Social Prevention in Mexico contemplates regulations and norms in this regard [6], in practice, work environments must ensure safety using different methods and techniques that allow evaluating prevailing conditions at present [7].

Awareness-building strategies are required for some textile companies' owners or managers in HidalgoMéxico about importance of employee's safety \& health and job satisfaction related to their work position in the company. In other words, before analysing or qualifying job posts in a more technical way, it is important to have initial evidence of signs or symptoms associated with tasks performed by employees in a specific section of the production process [8]. 
Initially in this research, the textile companies' owners declared that working conditions for their employees were mainly adequate. However, before doing any technical evaluation or qualification of job posts, it was proposed to them to obtain workers opinions and perceptions related to job satisfaction and general characteristics associated with their work positions, since, not only physical risk but also mental risk were important, this two factors combined become occupational well-being, significant for employees life and future [9]. Likewise, owners must understand that success and competitiveness in their organizations strongly depends on professional employee's performance [10].

Job satisfaction is the perceived balance of how and how much job characteristics adapts to worker expectations, causing a positive or negative affective orientation towards the job. It is also conceptualized as a positive emotional state result of a pleasant perception of work experience, alluding to aspects related to both content of the task and degree of interest, challenge, defiance, variety or learning opportunity, such as external conditions like salary, work hours and physical \& environmental conditions [11].

Herzberg's motivational theory proposed two types of task-related factors, intrinsic and extrinsic, which produce satisfaction and dissatisfaction. The former are associated with personal development, interest in the task, achievement, recognition, creativity, responsibility and possibility of promotion. The latter refer to organization's policy, quality of supervision, relationships with colleagues, salary and physical or environmental conditions. In addition, other characteristics such as age, education, gender and non-labour circumstances may also affect the levels or degrees of job satisfaction [12].

The purpose of this research was to evaluate the job posts in textile companies in Hidalgo-Mexico, through a job satisfaction instrument in aim of giving recommendations for technical evaluation and care. The study employs a transactional, descriptive and correlational methodology. Data was collected from 420 workers from various textile companies in HidalgoMexico. The job satisfaction scale used consist of 15 items on a 7 point Likert scale that range between "extremely dissatisfied" to "extremely satisfied" (1-7), based on the one created by Warr, Cook and Wall in 1979 and adapted to Spanish language by Pérez and Fidalgo in 1994 [11].

As can be seen in table 1, the means obtained from the 420 workers' opinion ranks below overall average in six factors, considering responses range from 1 to 7. For cases related to "The physical work conditions", "The recognition you get for good work", "Your rate of pay", "The opportunity to use your abilities", "The way the organization is managed" and "The amount of variety in your job"; workers are moderately dissatisfied.

Two factors ranked below 3, "Your chance of promotion/reclassification" and "The attention to suggestions you make", demonstrating that employees are clearly dissatisfied.

\begin{tabular}{|c|c|}
\hline \multicolumn{2}{|c|}{ JOB SATISFACTION IN WORKERS PER ITEM } \\
\hline Item description & Mean \\
\hline The physical work conditions & 3.43 \\
\hline $\begin{array}{l}\text { The freedom to choose your own method of } \\
\text { working }\end{array}$ & 4.21 \\
\hline Your fellow workers & 5.89 \\
\hline The recognition you get for good work & 3.92 \\
\hline Your immediate boss & 4.85 \\
\hline The amount of responsibility you are given & 5.12 \\
\hline Your rate of pay & 3.10 \\
\hline The opportunity to use your abilities & 3.45 \\
\hline $\begin{array}{l}\text { Industrial relations between management } \\
\text { and staff }\end{array}$ & 4.26 \\
\hline Your chance of promotion/reclassification & 2.95 \\
\hline The way the organization is managed & 3.71 \\
\hline The attention to suggestions you make & 2.65 \\
\hline Your hours of work & 4.62 \\
\hline The amount of variety in your job & 3.85 \\
\hline Your Job security & 5.20 \\
\hline
\end{tabular}

Exceeding overall average, 7 factors presents satisfactory levels about "The freedom to choose your own method of working", "Your fellow workers", "Your immediate boss", "The amount of responsibility you are given", "Industrial relations between management and staff", "Your hours of work" and "Your job security".

Table 2 shows the employees' levels of satisfaction/ dissatisfaction. It is observed that $36.7 \%$, corresponding to 154 workers (sum of last three factors), are included in the range of job satisfaction, while $48.1 \%$, referring to 202 employees (sum of the first three factors), presents levels of satisfaction that goes from very little to practically nothing. Finally, 64 workers $(15.2 \%)$ have a neutral opinion.

Table 2

OVERALL JOB SATISFACTION IN WORKERS

\begin{tabular}{|l|c|c|}
\hline \multicolumn{1}{|c|}{ Measurement factor } & $\begin{array}{c}\text { Number of } \\
\text { workers }\end{array}$ & $\begin{array}{c}\text { Percent } \\
\text { (\%) }\end{array}$ \\
\hline Extremely dissatisfied & 16 & 3.8 \\
\hline Very dissatisfied & 54 & 12.9 \\
\hline Moderately dissatisfied & 132 & 31.4 \\
\hline Not sure & 64 & 15.2 \\
\hline Moderately satisfied & 116 & 27.6 \\
\hline Very satisfied & 32 & 7.6 \\
\hline Extremely satisfied & 6 & 1.4 \\
\hline Total & $\mathbf{4 2 0}$ & $\mathbf{1 0 0}$ \\
\hline
\end{tabular}

Table 3 exhibits the means obtained in each working area inside the textile companies', finding the lowest scores in ironing, sewing and finishing areas. Only three areas show scores above average, protruding 
Table 3

\begin{tabular}{|l|c|c|}
\hline \multicolumn{3}{|c|}{$\begin{array}{c}\text { EMPLOYEES' JOB SATISFACTION PER WORKING } \\
\text { AREA }\end{array}$} \\
\hline \multicolumn{1}{|c|}{ Working area } & $\mathbf{N}$ & Mean \\
\hline Spinning & 55 & 3.62 \\
\hline Cutting & 70 & 3.11 \\
\hline Sewing & 82 & 2.44 \\
\hline Ironing & 56 & 1.88 \\
\hline Finishing & 42 & 2.80 \\
\hline Packaging & 35 & 3.22 \\
\hline Designing & 25 & 3.91 \\
\hline Warehouse & 30 & 4.14 \\
\hline Others & 25 & 3.57 \\
\hline Total/mean & 420 & 3.23 \\
\hline
\end{tabular}

the warehouse. General average of areas ranks below the mean, indicating that workers are not satisfied with the conditions they work in.

Finally, table 4 shows the regression analysis between levels of Job Satisfaction and the less qualified working area (Ironing). It presents a p-value (significance) less than 0.05 , in "The physical work conditions", "Your immediate boss" and "Your rate of pay", which indicates a relation with the outcome (dependent) variable, ironing working area.

\section{CONCLUSIONS}

The Job Satisfaction scale used to collect data from 420 workers of various textile companies reflects work force's opinion. Obtained means were found below the elements or dimensions means (from lowest to least low), associated to the attention to suggestions, chance of promotion, salary, physical work conditions and opportunity to use own abilities.

In general, dissatisfaction levels perceived by the textile companies' workers is close to $50 \%$, allowing to understand that, perhaps, employees' need to have a job is superior than the level of acceptance related to their expectations associated with the position they occupy, salary, general working conditions or another factors.

Considering that worst ranked area was ironing, its correlational analysis with each factor of scale's job satisfaction scale indicated a positive relationship with physical work conditions, your immediate boss and your rate of pay, supporting the first findings.

It is common for many textile companies in State of Hidalgo, Mexico being family businesses that managed their gradually growth based on their installed capacity, number of clients and assets or, at least, remaining within the field, nevertheless, operating conditions, both physical and environmental, have not improved in the same proportion.

This study reflects only the satisfaction levels comparison with one working area, so it is important to extend a research to the other areas and deepen into factors that could explain, more precisely, associated aspects to the managers or companies 'owners characteristics and profiles, which contributes to understand why growing has not been homogeneous.

In conclusion, based on these study findings, carrying out, in the short term, investigations that allows

REGRESSION ANALYSIS TO EXAMINE THE IRONING WORKING AREA AS THE OUTCOME VARIABLE

\begin{tabular}{|c|c|c|c|c|c|c|}
\hline \multirow[b]{2}{*}{ Item description } & \multicolumn{2}{|l|}{ Model 1} & \multicolumn{2}{|l|}{ Model 2} & \multicolumn{2}{|l|}{ Model 3} \\
\hline & $\begin{array}{c}\text { Coefficient Std. } \\
\beta\end{array}$ & $\mathbf{p}$ & $\begin{array}{c}\text { Coefficient Std. } \\
\beta\end{array}$ & p & $\begin{array}{c}\text { Coefficient Std. } \\
\beta\end{array}$ & p \\
\hline The physical work conditions & -0.031 & 0.734 & & & 0.289 & 0.000 \\
\hline $\begin{array}{l}\text { The freedom to choose your own } \\
\text { method of working }\end{array}$ & 0.302 & 0.610 & & & & \\
\hline Your fellow workers & 0.019 & 0.752 & & & & \\
\hline The recognition you get for good work & 0.043 & 0.605 & & & & \\
\hline Your immediate boss & 0.185 & 0.047 & 0.136 & 0.047 & 0.156 & 0.022 \\
\hline $\begin{array}{l}\text { The amount of responsibility you arc } \\
\text { given }\end{array}$ & 0.063 & 0.445 & & & & \\
\hline Your rate of pay & & & -0.158 & 0.022 & -0.161 & 0.020 \\
\hline The opportunity to use your abilities & -0.023 & 0.823 & & & & \\
\hline $\begin{array}{l}\text { Your chance of promotion/reclassifica- } \\
\text { tion }\end{array}$ & 0.004 & 0.953 & & & & \\
\hline The way the organization is managed & -0.085 & 0.190 & & & & \\
\hline The attention to suggestions you make & 0.006 & 0.931 & & & & \\
\hline Your hours of work & -0.010 & 0.869 & & & & \\
\hline The amount of variety in your job & 0.091 & 0.161 & & & & \\
\hline Your job security & 0.045 & 0.496 & & & & \\
\hline
\end{tabular}


evaluating or qualifying job posts technically is the next step to follow, in order to lay foundations for every associated conditions and propose changes that allows improving employees' performance, decreasing health risks and increasing job satisfaction.

\section{ACKNOWLEDGEMENTS}

The authors wish to express their gratitude to the companies that collaborated in the study, to the Autonomous University of the State of Hidalgo and to the Institute of Economic and Administrative Sciences, for allowing and supporting research.

\section{REFERENCES}

[1] Diamantidis, A., Chatzoglou, P., Factors affecting employee performance: an empirical approach, In: International Journal of Productivity and Performance Management, 2018, 68, 1, 171-193

[2] Muda, I., Rafiki, A., Reseki, M., Factors Influencing Employees' Performance: A Study on the Islamic Banks in Indonesia, In: International Journal of Business and Social Science, 2014, 5, 2, 73-80

[3] Selvaraj, M., Selva, K., A study on influence of organizational factors on performance of textile industrial units, In: International Journal of Pure and Applied Mathematics, 2018, 119, 16, 3975-3979

[4] Urošević, S., Đorđević, D., Radosavljević, D., Kokeza, G., Stefanović, V., Multicriteria ranking of a job positions by ELECTRA methods in order to improve the analysis and conditions at work in companies in the textile industry, In: Industria Textila, 2017, 68, 5, 388-395, https://doi.org/10.35530/IT.068.05.1378

[5] Crespi-Vallbona, M., Mascarilla-Miró, O., Job satisfaction. The case of information technology (IT) professionals in Spain, In: Universia Business Review, 2017, 1, 1, 36-51

[6] Patlán, J., Derechos laborales: una mirada al derecho a la calidad de vida en el trabajo, In: Ciencia Ergo Sum, 2016, 23, 2, 121-133

[7] Stoewen, D., Wellness at work: Building healthy workplaces, In: The Canadian Veterinary Journal, 2016, 57, 11, 1188-1190

[8] Gonzales, C., Inche, J., Modelo de análisis y evaluación de riesgos de accidentes en el trabajo para una empresa textil, In: Gestión y producción, 2014, 7, 1, 33-41

[9] Camacho, A., Mayorga, D., Riesgos laborales psicosociales. Perspectiva organizacional, jurídica y social, In: Revista Prolegómenos - Derechos y Valores, 2017, 20, 40, 159-172

[10] Girneata, A., GiurGiu, A., Cosmin, O., Popa, I., Performance management practices in Romanian textile and clothing companies, In: Industria Textila, 2015, 66, 2, 108-113

[11] Gandarrillas, M., Vázquez, L., Márquez, H., Santamaría, E., Garaña, O., Santibáñez, M., Job satisfaction and perceived social support among workers from a tertiary hospital, In: Medicina y Seguridad del Trabajo, 2014, 60, 234, 64-89

[12] Alshmemri, M., Shahwan-Akl, L., Maude, P., Herzberg's Two-Factor Theory, In: Life Science Journal, 2017, 14, 5, $12-16$

Authors:

\section{TIRSO JAVIER HERNÁNDEZ-GRACIA, DANAE DUANA-AVILA}

Autonomous University of the State of Hidalgo, Institute of Economic and Administrative Sciences,

Academic Area of Administration, La Concepción circuit, km 2.5, San Juan Tilcuautla Municipality of San Agustín

Tlaxiaca, Hidalgo, 42161, Pachuca Hidalgo, México

e-mail: thernan@uaeh.edu.mx

Corresponding author:

DANAE DUANA-AVILA

e-mail: duana@uaeh.edu.mx 